\title{
Kültürel Miras Alanları Üzerine Bir Meta Analizi: Safranbolu İlçesi Örneği ${ }^{*}$
}

\author{
Yrd. Doç. Dr. Nurettin AYAZ
}

Karabük Üniversitesi, Safranbolu Turizm Fakültesi, Turizm İşletmeciliği Bölümü, e-posta: nurettinayaz@karabuk.edu.tr

Ömer Ceyhun APAK

Karabük Üniversitesi, Sosyal Bilimler Enstitüsü, İşletme ABD, e-posta: ceyhun.apak@hotmail.com

Kübra SÜNBÜL

Karabük Üniversitesi, Sosyal Bilimler Enstitüsü, Turizm İşletmeciliği ABD, e-posta: kubra94sunbul@gmail.com

Öz

Miras turizmi, geçmişin varoluşsal değerinin/değerlerinin (somut yapılar, soyut deneyimler, kültür ve gelenek) modern toplum için ticari bir etkinlik kaynağı olarak korunması esası üzerine kuruludur. Bununla birlikte birçok turizm çekim merkezi, sahip bulunduğu mirassal zenginliklerini korumada ve gelecek kuşaklara aktarmada sıkıntılar yaşamaktadır. Bu sıkıntıların aşılması sürecinde bilimsel çalışmalara vurgu yapılmakta ve destek olması beklenmektedir. Ancak yapılan bilimsel çalışmalar, çoğunlukla birbirinden habersiz, yazarın/yazarların kişisel görüşüne dayalı veya birbirine benzer bir görünüm sergilemektedir. Özellikle farklı disiplinlerde hazırlanan çalışmalar, sadece kendi disiplini içerisinde kalmakta, diğer disiplinlere sonuçları ulaşamamakta veya çok az ulaşmaktadır. Bu araştırmanın temel amacı Dünya Miras Listesi içerisinde yer alan ve kültürel bir değer olarak korunması öngörülen Safranbolu ilçesinin turizmine yönelik farklı disiplinlerdeki çalışmaları Meta Analizi kapsamında irdelemek ve miras turizmi kapsamında destinasyonun geleceğine yönelik bir bakış açısı oluşturmaktır. Çalışma, nitel araştırma yöntemi kapsamında içerik analizi tekniği kullanılarak gerçekleştirilmiştir. Araştırma sonuçları göstermiştir ki Safranbolu; turizm, coğrafya, mimarlık, sanat tarihi ve sosyoloji disiplinlerinin ilgi alanı konumundadır. Kültürel mirasın korunması, sürdürülebilirlik, turizm planlaması, turizm çeşitlendirme, taşıma kapasitesi, bilinç oluşturma, misafir kabul eden toplumun ve ziyaretçilerin düşünceleri çalışmalarda öne çıkartılmıştır.

Anahtar Kelimeler: Kültür, Kültürel miras, Meta analiz, Safranbolu.

\section{Önerilen Atıf:}

Ayaz, N., Apak, Ö. C. ve Sünbül, K. (2018). Kültürel Miras Alanları Üzerine Bir Meta Analizi: Safranbolu İlçesi Örneği, Türk Turizm Araştırmaları Dergisi, Cilt.2, Sayı.1, ss.1-14.

\footnotetext{
* Uluslararası Turizm ve Kültürel Miras Kongresi (04-08 Ekim 2017) kapsamında özet bildiri olarak sunulmuştur.
} 


\title{
A Meta-Analysis on Cultural Heritage Sites: Case Study of Safranbolu
}

\author{
Assistant Prof. Dr. Nurettin AYAZ \\ Karabük University, Safranbolu Faculty of Tourism, e-mail: nurettinayaz@karabuk.edu.tr \\ Ömer Ceyhun APAK \\ Karabük University, Social Sciences Institute, e-mail: ceyhun.apak@hotmail.com \\ Kübra SÜNBÜL \\ Karabük University, Social Sciences Institute, e-mail: kubra94sunbul@gmail.com
}

\begin{abstract}
Heritage tourism aims to protect the existential values of the past as a means of commercial activity for modern society. Many tourism centers of attraction experience difficulties to sustain and pass on their inheritances to next generations. On one hand, it is reasonably expected that both academic researches and to finance these researches will help to overcome those difficulties. On the other, academic surveys and studies on the topic give the impression of either replicating each other or being conducted independently or on the subjective standpoints of their authors. Studies in different disciplines generally stay within the boundaries of their respective disciplines and barely reach or completely fail to find voice in other disciplines. Therefore, it is the chief objective of this study to examine the studies of different disciplines on Safranbolu, included in the World Heritage List to be protected as a cultural value, within meta-analysis and provide a new perspective on the future of destination in the context of heritage tourism. The present study further applies content analysis within qualitative research method and concludes that Safranbolu is at intersection point of tourism, geography, architecture, art history and sociology while giving special emphasis on the protection of cultural heritage, sustainability, tourism planning, diversity in tourism, transport capacity, consciousness building as well as on the thoughts of host society and guests.
\end{abstract}

Keywords: Culture, Cultural heritage, Meta-analysis, Safranbolu.

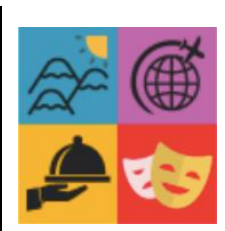

Journal of Turkish Tourism Research Vol. 2, Issue.1, 2018

pp.1-14.

DOI: 10.26677/tutad.2018.

Suggested Citation: Ayaz, N., Apak, Ö. C. ve Sünbül, K (2018). A Meta-Analysis on Cultural Heritage Sites: Case Study of Safranbolu, Journal of Turkish Tourism Research, Vol.2, Issue.1, pp.1-14. 


\section{Gíriș}

Tarihi kentler, geleneksel kent dokuları ile kültürel ve mekânsal olarak yaşanan geçmişi yansıtan unsurlardır. Bir toplumdaki mimari, yaşayış, sanat, gelenek ve düşünceleri gelecek kuşaklara taşıma özellikleriyle oldukça önemlidirler. Günümüzde geçmiş uygarlıkların yaşadığı kentlerin mimari özellikleri, yaşam felsefeleri ve sosyokültürel yapıları kültürel miras kavramıla ilişkilendirilmektedir (Koçan ve Çorbacı, 2012; Ceylan ve Somuncu, 2016). Kültürel miras, geçmişten günümüze kalan değerleri (peyzajlar, tarihi mekânlar, biyoçeşitlilik, kültürel uygulamalar vb.) kapsayan ulusal, bölgesel ve yerel anlamda büyümeye ve gelişmeye etki ederek modern yaşamın önemli bir parçası haline dönüşmüştür (Doğaner ve Dupont, 2015).

Mirassal değerlerin bulunduğu yerler, turizmle birlikte ekonomik büyüme ve gelişme sağlama özellikleri ile öne çıar hale gelmiştir. Turistlerin bir ülke veya bölge kültürünü, miras değerini, yaşam tarzını merak etmesi ve deneyimlemek istemesi miras turizmini ön plana çıarmış ve yeni destinasyonların ortaya çımmasına öncülük eder hale ulaşmıştır (Uslu ve Kiper, 2006; Boz ve Uğur, 2015).

Türkiye turizmi için Safranbolu ilçesi, sahip olduğu mimari değerleri ile kültürel miras turizmi kapsaminda önemli destinasyonlardan bir tanesidir. Safranbolu'nun UNESCO dünya miras listesi içerisinde yer alması ve konumu, turistleri cezbetmekte ve önemli bir destinasyon olarak önemini artırmaktadır (Gürbüz, 2002a; Türker, 2013). Bu araştırmada, kültürel bir varış noktası olarak kabul edilen ve korunması öngörülen Safranbolu ilçesine yönelik farklı disiplinler çerçevesinde yapılan çalışmalar Meta Analizi kapsamında irdelenmekte, kültür turizmi bağlamında destinasyonun geleceğine yönelik bir perspektif oluşturulmasına disiplinler arası destek sağlanması amaçlanmaktadır.

\section{LITERATÜR İNCELEMESİ}

Ziyaret gerçekleştirilen bölgedeki yerel insanların karakterlerini ve mirasını öğrenmeye odaklı bir turizm türü olan kültür turizminde (Lynch vd., 2011) ana öğe kültürdür. Bireyin üyesi olduğu toplumun sahip bulunduğu bilgi, gelenek, sanat, inanç ve adetleri içeren kültür, Latince'de "bakmak" veya "yetiştirmek" anlamına gelmekte ve "bir toplumun sahip olduğu maddi ve manevi değerler" olarak tanımlanmaktadır (Kalamarova vd., 2015). Kültür, Almanya'da 1750 'li yıllardan sonra ortaya çıkan gelişmeler sonucu insan zihninin oluşturduğu bir değer olarak kullanılmaya başlanmıştır. Bununla birlikte ilerleyen süreçte insanların sanatları, gelenekleri, yetenek ve becerileri kültür varlığı olarak anlam kazanmıştır (Uygur ve Baykan, 2007).

Kültür varlıkları, belirli bir toplumun oluşturduğu kültürel ve bilimsel değere sahip taşınır veya taşınmaz eserler olup, farklı toplumlar tarafından doğal yaşamdaki çeşitli zorluklara karşı üretilen ürünlerdir. Bu varlıklar yenilenerek veya kendi öz değerini koruyarak günümüze kadar ulaşmaktadır. Bu bağlamda toplumu oluşturan temel öğeler ve kültür birikimi kültürel miras olarak kabul edilmektedir. UNESCO, kültürel mirası “önceki kuşaklar tarafından dil, kültür, eser gibi yaşanmışlıklardan günümüze kalanlara verilen bir isim" olarak tanımlamaktadır (Külcü, 2015: 28).

Kültürel mirasın sadece mimari varlıklar açısından değil, aynı zamanda bu eserleri oluşturan bilgi birikimlerinin, geleneklerin ve insani değerlerin yansıması olarak ta değerlendirilmesi gerektiğini vurgulanmaktadır (İsmail, Masron ve Ahmad, 2014). Bu açıdan kültürel miras olarak ifade edilen dokunulabilir (insanların ürettiği araç gereçler, teknolojik ürünler ve yapılar) değerler somut miras, dokunulamayan (davranışlar, değerler ve kurallar) değerler ise 
soyut miras şeklinde iki grupta incelenmektedir. Somut ve soyut miras değerleriyle ilgili olarak insanların ürün ve hizmetleri doğrudan veya dolaylı olarak satın alması miras turizmi olgusunu ortaya çıkarmaktadır (Lenzerini, 2011; Gülcan, 2010; Yılmaz, Karaman ve Karaman, 2013; Fitri, Ahmad ve Ahmad, 2015).

Turizmin hayat kaynağ getirilmesiyle turistlerin değişen motivasyonlarına bağlı olarak miras turizmi gerçekleşmektedir (Boniface ve Fowler, 1993). Birçok somut ve soyut değerlere sahip olan Türkiye, miras turizmi açısından çok zengindir. Saraylar, antik kentler, hanlar, ören yerleri gibi birçok kültürel varlıklar turizm açısından çekicilik unsuru oluşturmaktadır. Efes Antik Kenti, Topkapı Sarayı, Aspendos Antik Tiyatrosu, Kapadokya ve bunun yanında pek çok miras değerleri günümüzde turistik ürün olarak kullanılabilmektedir. Köy yaşam tarzları, köy kıyafetleri, geleneksel el sanatları, gelenek ve görenekler gibi kültürel unsurlar da halihazırda turistik ürün olarak değerlendirilebilmektedir (Türker ve Çelik, 2012). Bununla birlikte Türkiye turizminde Osmanlı kent mimarisi, yiyecek ve içecekleri, gelenek ve görenekleri, yaşam tarzı gibi kültürel miras değerleri ile Safranbolu ilçesi miras turizmi açısından ön plana çıkmaktadır.

Tarihi kültürel değerlere sahip olan ve bozulmadan günümüze kadar ulaşan Osmanl1-Türk mimarisine sahip olan Safranbolu UNESCO tarafından 1994 yılında Dünya Miras Listesine alınmıştır. Sanat ve mimari değerler açısından birçok yapıya sahip olmasının yanında doğal güzelliklerin ve kültürel zenginliklerin olması Safranbolu'nun turistik ürün çeşitliliğini artırmaktadır (Gürbüz, 2002a). Bu bağlamda Safranbolu'da mirassal değerler ve turizm türleri bakımından çekicilik unsuru oluşturan turistik alanlar Tablo 1'de gösterilmektedir.

Tablo1'de görüldüğü üzere Safranbolu doğal ve kültürel çekicilikleri ile farklı disiplinlerde (turizm, sosyoloji, mimarlık, coğrafya, sanat tarihi vb.) araştırma yapılabilecek bir akademik çekim alanı konumundadır. Yüksek Anıtlar Kurulunun Safranbolu'yu "Kentsel Sit" ilan etmesiyle birlikte akademik anlamda kente olan ilgiyi artırmaktadır. Kentin turizm açısından gelişme göstermesi ve turistler açısından ilgi odağı olmaya başlaması da çeşitli araştırmaların yapılmasında tetikleyici olmaktadır. Özellikle kentin kültürel değerleri, kültürel miras alanlarının korunması ve sürdürülebilirliği, yerel halkın turizm algılaması gibi konularda birçok çalışma yapılmış ve yapılmaya da devam edilmektedir (Boz ve Uğur, 2015).

Tablo 1: Safranbolu ve Çevresindeki Potansiyel Turistik Alanlar

\begin{tabular}{|l|l|}
\hline Turizm Çeşitleri & Safranbolu ve Çevresindeki Turistik Alanlar \\
\hline Kültür Turizmi & Tarihi Safranbolu evleri \\
& Kent müzeleri \\
& Tarihi camiler \\
& Yörük Köyü ve Yazı Köy'deki tarihi ve kültürel değerler \\
& Tarihi çeşmeler, hamamlar, köprüler, su kemeri, han \\
& Türbeler, Tekkeler \\
& St. Stefanos Kilisesi (Ulu Camii) \\
& Kaya Mezarları \\
& Hadrianapolis antik şehri \\
& Küçük Düz Yaylası, Avdan Yaylası, Boduroğlu Yaylası, Çakı̈ören \\
& Yaylası, Sorgun Yaylası, Dede Yaylası, Büyük Düz Yaylası, Ulu \\
& Yayla, Eğri Ova Mesire Yeri, Küçük Yayla, Arıcak Yaylası, Sarıçiçek \\
& Yaylası, Gök tepe Yaylası, Çetiören Mesire Alanı, Eflani Mesire \\
\hline Yayla Turizmi & Alanı, \\
\hline Doğa Turizmi & Şeker Kanyonları, Keltepe, Tokatlı, Düzce ve Sakaralan (Konarı) \\
\hline Mağara Turizmi & Bulak (Mencilis) Mağarası, Hıar Mağarası \\
\hline
\end{tabular}

Kaynak: Gürbüz, 2002a: 52. 


\section{YÖNTEM}

Nitel araştırma yöntemi kapsamında hazırlanan bu çalışmada, Safranbolu destinasyonuna yönelik çalışmalar kaynak dokümanlar olarak kabul edilmiş ve içerik analizi kapsamında değerlendirilmektir. Araştırma kapsamında toplanan veriler içerik analizi yöntemi ile tarihsel yaklaşım kapsamında incelenmektedir

Harris (2001) içerik analizi için işlem basamaklarını araştırma sorusunu veya sorularını belirleme, örneklem, analiz birimlerini belirleme, kullanılacak kategorileri saptama, kodlama yapma, geçerlilik ve güvenilirliği tespit etme aşamalarının içerik analizi sürecini oluşturduğunu ifade etmektedir. Bu bağlamda bu çalışma için araştırma sorusu aşağıdaki şekilde öngörülmüştür: Safranbolu ilçesine yönelik akademik anlamda yapılan çalışmalar, nasıl bir görünüm sergilemektedir?

Araştırmanın örneklemini, 1995-2017 dönemlerinde Safranbolu kenti üzerine yapılan 44 akademik çalışma oluşturmaktadır. Analiz birimleri olarak turizm, mimarlık, sosyoloji coğrafya ve sanat tarihi disiplinleri kabul edilmiş, araştırma Safranbolu'ya yönelik bu disiplinlerde gerçekleştirilmiş çalışmalar etrafında şekillendirilmiştir.

\section{BULGULAR}

Araştırmada Safranbolu ilçesi üzerine yapılmış olan çeşitli disiplinlerdeki çalışmalar tarihsel yaklaşımla (tarih sürecinde yapılmış çalışmaların dokümanlara bağlı olarak incelenmesi) kronolojik olarak incelenmiş olup bilim dallarına göre yüzdelik dağılımları belirlenmiştir.

Tablo 2: Safranbolu'ya Yönelik Araştırmaların (1995-2017) Disiplinlere Göre Dağılımı

\begin{tabular}{|l|c|c|}
\hline Anabilim Dalı & $\mathbf{n}$ & $\mathbf{\%}$ \\
\hline Turizm & 21 & 47,8 \\
\hline Mimarlık & 15 & 34,2 \\
\hline Sosyoloji & 2 & 4,5 \\
\hline Coğrafya & 4 & 9,0 \\
\hline Sanat Tarihi & 2 & 4,5 \\
\hline Toplam & 44 & 100 \\
\hline
\end{tabular}

Tablo 2'ye göre yapılan 44 araştırmanın 21'i $(\% 47,8)$ turizm alanında, 15'i $(\% 34,2)$ mimarlık alanında, 2'si $(\% 4,5)$ sosyoloji alanında, 4'ü $(\% 9,0)$ coğrafya alanında ve 2'si $(\% 4,5)$ sanat tarihi alanında yapılmıştır. Bu sonuçlara göre araştırmaların disiplinlere göre öncelik sırası; turizm, mimarlık, coğrafya, sosyoloji ve sanat tarihi şeklindedir.

Tablo 3 kapsamında Safranbolu'nun mirassal değerleri üzerine yapılan çalışmalar bilim dallarına göre kronolojik olarak incelendiğinde, en çok çalışma yapılan yıl 14 çalışma ile 2015 yılı olmuştur. 2013 ve 2016 yılları ise 7'şer çalışma ile ikinci sırada yer almıştır. Yapılan çalışmaların son yıllarda artış göstermesinde 2007 yılında kurulmuş olan Karabük Üniversitesi'nin etkisinin olduğu söylenebilir. Üniversite bünyesinde farklı anabilim dallarındaki araştırmacılar için Safranbolu'nun tarihi kültürel miras değerleri önemli ve cezp edici bir çalışma ortamı olarak öne çıkmaktadır. 
Tablo 3. Safranbolu'ya Yönelik Araştırmaların (1995-2017) Kronolojik Dağılımı

\begin{tabular}{|c|c|c|c|c|c|c|c|c|c|c|c|c|c|c|c|}
\hline & $\begin{array}{l}\text { Һू } \\
\text { - }\end{array}$ & ธ్రి & ઠิे & ఫ્రి & ڤે & ઠ્ંે & 옥 & 코ํ & సิ่ & ஸे & ت゙્ે & 竞 & ัํ & సิे & $\stackrel{\pi}{0}_{0}^{0}$ \\
\hline 苞 & & & 2 & & & & & 3 & 1 & 2 & & 7 & 5 & 1 & $\begin{array}{l}2 \\
1\end{array}$ \\
\hline 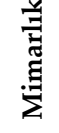 & 1 & & & 1 & & & 1 & & & 4 & 1 & 5 & 1 & 1 & $\begin{array}{l}1 \\
5\end{array}$ \\
\hline $\begin{array}{l}:-\frac{1}{0} \\
0 \\
0 \\
0 \\
0 \\
\infty\end{array}$ & & & & & & & & & & 1 & & 1 & & & 2 \\
\hline 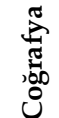 & & 1 & 1 & & 1 & & & & & & & & 1 & & 4 \\
\hline 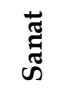 & & & & & & 1 & & & & & & 1 & & & 2 \\
\hline 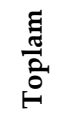 & 1 & 1 & 3 & 1 & 1 & 1 & 1 & 3 & 1 & 7 & 2 & $\begin{array}{l}1 \\
4\end{array}$ & 7 & 2 & $\begin{array}{l}4 \\
4\end{array}$ \\
\hline
\end{tabular}

Tablo 4 verileri kapsamında Safranbolu ilçesine yönelik turizm araştırmalarında eğitim (yöre halkının turizm konusunda eğitim alması, yerel düzeyde bilinç oluşturulması, turizm eğitimine ilköğretim öğrencileri düzeyinde başlanması), pazarlama (potansiyel turistik değerlerin turizm hizmetine sunumu, kültürel miras değerlerinin öne çıkarılması, destinasyona kültür turizmine ek olarak kongre turizminde taşınması, konak yöneticilerini kültür turizmine katılan turistlerin beklentileri konusunda bilgilendirilmesi, yabancı turistlerin Safranbolu imaj algılarına önem verilmesi, Yörük Köyü ve çevresinde eko turizm geliştirilmesi, Safranbolu turizmi gelişme aşamasını tamamlamış ve olgunluk aşamasına geçmiştir, Safranbolu'yu ziyaret eden yerli turistlerin yiyecek-içecek beklentileri; hijyen, hizmet sunumu, yemekler ve salon atmosferi 
Tablo 4. Safranbolu'ya Yönelik Turizm Disiplini Araştırmaları ve Tespitler

\begin{tabular}{|c|c|}
\hline Yazar/Yazarlar & Tespitler \\
\hline Gürbüz (2002a) & $\begin{array}{l}\text { Safranbolu'yu ziyaret eden turistler ile yöre halkı arasındaki olumsuz durumları } \\
\text { ortadan kaldırabilmek için yöre halkının turizm konusunda eğitim alması } \\
\text { gerekmektedir. }\end{array}$ \\
\hline Gürbüz (2002b) & $\begin{array}{l}\text { Safranbolu'da turizmin sağladığı avantajlardan daha fazla faydalanmak için } \\
\text { potansiyel turistik değerlerin turizm hizmetine açılması gerekmektedir. }\end{array}$ \\
\hline $\begin{array}{l}\text { Kaya ve Kurt } \\
(2011)\end{array}$ & $\begin{array}{l}\text { Safranbolu'da bulunan kültürel miras değerlerinin turizm potansiyeli açısından } \\
\text { öne çıkarılması gerekmektedir. }\end{array}$ \\
\hline $\begin{array}{l}\text { Karakuş, Çepni ve } \\
\text { Kılcan (2011) }\end{array}$ & $\begin{array}{l}\text { Safranbolu'nun turizm faaliyetleri konusunda yerel düzeyde bilinç oluşturulması } \\
\text { için ilköğretim öğrencileri düzeyinde eğitime başlanması gerekmektedir. }\end{array}$ \\
\hline Özdemir (2011) & $\begin{array}{l}\text { Safranbolu'da kültürel miras kaynaklarının kontrolsüz şekilde kullanılarak } \\
\text { pansiyon tarzı işletmelere dönüştürülmesinin orijinalliği bozmaktadır. }\end{array}$ \\
\hline $\begin{array}{l}\text { Koçan ve Çorbacı } \\
(2012)\end{array}$ & $\begin{array}{l}\text { Safranbolu kongre turizmi açısından önemli bir potansiyele sahip bulunmaktadır. } \\
\text { Coğrafi bilgi sistemleri analizi yardımıla kongre turizmi geliştirilmelidir. }\end{array}$ \\
\hline Yüksel (2013) & $\begin{array}{l}\text { Turizm faaliyetlerini sürdürmek için yeni binaların yapılması yerine mevcut yapı } \\
\text { stokundan faydalanılması daha uygun olacaktır. }\end{array}$ \\
\hline $\begin{array}{l}\text { Türker ve Uçar } \\
(2013)\end{array}$ & $\begin{array}{l}\text { Safranbolu'da faaliyet gösteren konaklama işletmeleri, sosyal sorumluluk } \\
\text { konusunda duyarlı bir görünüm sergilemektedir. }\end{array}$ \\
\hline $\begin{array}{l}\text { Ayaz, Apak ve } \\
\text { Batı (2015) }\end{array}$ & $\begin{array}{l}\text { Safranbolu'daki konak yöneticilerini kültür turizmine katılan turistlerin beklentileri } \\
\text { konusunda bilgilendirilmelidir. }\end{array}$ \\
\hline $\begin{array}{l}\text { Ayaz, Batı ve } \\
\text { Gökmen (2015) }\end{array}$ & $\begin{array}{l}\text { Yabancı turistlerin Safranbolu imaj algıları şehir imajı, rehberlik hizmetleri ve } \\
\text { ulaşım hizmetleri perspektifinde şekillenmektedir. }\end{array}$ \\
\hline $\begin{array}{ll}\text { Boz ve Uğur } \\
(2015)\end{array}$ & Safranbolu'da konaklama işletmeleri düşük kapasite ile çalışmaktadır. \\
\hline $\begin{array}{l}\text { Dönmez, Gökyer } \\
\text { ve Aşkın (2015) }\end{array}$ & $\begin{array}{l}\text { Safranbolu Yörük Köyü ve çevresinde ekoturizm geliştirilmesi halinde turizm daha } \\
\text { da gelişecektir. }\end{array}$ \\
\hline $\begin{array}{l}\text { Eker, Şengel ve } \\
\text { Zengin (2015) }\end{array}$ & $\begin{array}{l}\text { Safranbolu'da turizm Doxey yaklaşımına göre coşku aşamasındadır. Tarihsel ve } \\
\text { doğal yapıyı koruma ve yerel halkın turizmden para kazanma isteği coşku } \\
\text { nedenleridir. }\end{array}$ \\
\hline $\begin{array}{l}\text { Karakaya ve Uçar } \\
(2015)\end{array}$ & $\begin{array}{l}\text { Safranbolu'daki konaklama işletmelerindeki işgörenler, ücret esnekliği } \\
\text { uygulamalarında orta düzeyde katılım göstermektedirler. }\end{array}$ \\
\hline Yaman (2015) & $\begin{array}{l}\text { Yabancı turistler, Safranbolu'daki trafik düzenin kötü, eski evlerin çatısındaki } \\
\text { güneş enerji panelleri ve uydu alıcılarının görüntü kirliliği oluşturduğunu } \\
\text { düşünmektedir. }\end{array}$ \\
\hline $\begin{array}{l}\text { Diker ve } \\
\text { Çetinkaya (2016) }\end{array}$ & $\begin{array}{l}\begin{array}{l}\text { Safranbolu'daki konaklama işletmeleri engelli bireylere fazla imkânlar } \\
\text { sunamamaktadır. }\end{array} \\
\end{array}$ \\
\hline $\begin{array}{l}\text { Ceylan ve } \\
\text { Somuncu (2016) }\end{array}$ & Safranbolu'da turizmi çeşitlendirme fikri, doğal peyzajı bozabilir. \\
\hline $\begin{array}{l}\text { Gürbüz, Cengiz ve } \\
\text { Cengiz (2016) }\end{array}$ & $\begin{array}{l}\text { Safranbolu ve Beypazarı ilçelerini ziyaret eden turistlerin algılamaları ve } \\
\text { destinasyona yönelik tutumları farklılık göstermektedir. } \\
\end{array}$ \\
\hline $\begin{array}{l}\text { Ayaz ve Demirkol } \\
(2016)\end{array}$ & $\begin{array}{l}\text { Safranbolu'da turizm gelişme aşamasını tamamlamış ve olgunluk aşamasına } \\
\text { geçmiştir. Turizmin bu aşamada sürdürülebilirliği için paydaşlarının fikirleri } \\
\text { alınmalı ve birlikte çalışmaları sağlanmalıdır. }\end{array}$ \\
\hline $\begin{array}{l}\text { Düzgün ve Acar } \\
\text { (2016) }\end{array}$ & $\begin{array}{l}\text { Safranbolu'daki somut ve somut olmayan kültürel mirasın sürdürülebilirliği için } \\
\text { korunması gerekmektedir. }\end{array}$ \\
\hline $\begin{array}{lll}\begin{array}{l}\text { Ayaz } \\
(2017)\end{array} & \text { ve } & \text { Yalı }\end{array}$ & $\begin{array}{l}\text { Safranbolu'yu ziyaret eden yerli turistlerin yiyecek-içecek beklentileri; hijyen, } \\
\text { hizmet sunumu, yemekler ve salon atmosferi öncelik sırasındadır. }\end{array}$ \\
\hline
\end{tabular}


Tablo 5. Safranbolu'ya Yönelik Mimarlık Disiplini Araştırmaları ve Tespitler

\begin{tabular}{|c|c|}
\hline Yazar/Yazarlar & Tespitler \\
\hline $\begin{array}{l}\text { Hacısalihoğlu } \\
(1995)\end{array}$ & $\begin{array}{l}\text { Safranbolu'da yeni yerleşim yerlerinin ortaya çıkması tarihi çarşının } \\
\text { korunmasını olumsuz yönde etkilemektedir. }\end{array}$ \\
\hline $\begin{array}{l}\text { Harputlugil ve } \\
\text { Çetintürk (2005) }\end{array}$ & $\begin{array}{l}\text { Safranbolu, Hacı Hüseyinler Evi için bilgisayar programı yardımıyla } \\
\text { uygulanan ısıl konfor analizi yapılmıştır. Evde 1Sı kaybının olması, } \\
\text { pencerelerin tek cam olmasıdır. }\end{array}$ \\
\hline $\begin{array}{l}\text { Seker, Altan, } \\
\text { Kutoğlu, Akçın ve } \\
\text { Kahya (2010) }\end{array}$ & $\begin{array}{l}\text { Safranbolu'daki tarihi binaların 3D modellemesi kullanılmıştır. 3D } \\
\text { modeli binanın yapısını geliştirme ve görsel unsurlarını inceleme } \\
\text { açısından önem arz etmektedir. }\end{array}$ \\
\hline Bozkurt (2013) & $\begin{array}{l}\text { 19. yüzyılın sonlarında batılılaşma etkisiyle Safranbolu'da yer alan bazı } \\
\text { evlerin iç mekân tasarımında değişiklikler yapılmıştır. }\end{array}$ \\
\hline $\begin{array}{l}\text { Bozkurt ve } \\
\text { Altınçekiç (2013) }\end{array}$ & $\begin{array}{l}\text { Safranbolu'da avluların genel olarak konutun ön/yan kısmında veya } \\
\text { arka kısmında yer aldığı ve bahçeyle bütünleşik olduğu tespit } \\
\text { edilmiştir. }\end{array}$ \\
\hline Gezer (2013) & $\begin{array}{l}\text { Safranbolu'da evler doğru konumlandırılmalarılyla eko sistemi } \\
\text { bozmayıp ve bitki örtüsünü koruyarak sürdürülebilirliği sağlanmıştır. }\end{array}$ \\
\hline $\begin{array}{l}\text { İşler ve Aras } \\
\text { (2013) }\end{array}$ & $\begin{array}{l}\text { Kastamonu merkez, Daday ve Safranbolu'da incelenen ev tavanlarının } \\
\text { yapımında çam türü ahşap malzeme kullanılmıştır. Tavanlarda estetik } \\
\text { görünüme önem verilmiştir. }\end{array}$ \\
\hline Bayazit (2014) & $\begin{array}{l}\text { Safranbolu'da toplumun ekonomik yapısı ve kültürel gereksinimler } \\
\text { tamamen değişmesi evlerin otel olarak hizmet vermesine neden } \\
\text { olmuştur. }\end{array}$ \\
\hline $\begin{array}{l}\text { Dönmez, } \\
\text { Özyavuz ve } \\
\text { Gökyer (2015) }\end{array}$ & $\begin{array}{l}\text { Safranbolu'da toplu konut ve sitelerin seçilmesinde en büyük etkenler; } \\
\text { rekreasyon alanları, çocuk oyun alanları, spor alanları, güvenlik, } \\
\text { otopark, ve bitkisel düzenlemelerdir. }\end{array}$ \\
\hline $\begin{array}{l}\text { Kilıç ve Türkoğlu } \\
\text { (2015) }\end{array}$ & $\begin{array}{l}\text { Safranbolu'da geleneksel kent dokusunun korunması ve sürdürülmesi } \\
\text { için çok yönlü, bütüncül ve sürekliliği olan yönetim planlama sistemi } \\
\text { benimsenmelidir. }\end{array}$ \\
\hline $\begin{array}{l}\text { Kilıç ve Türkoğlu } \\
\text { (2015b) }\end{array}$ & $\begin{array}{l}\text { Safranbolu'da geleneksel evlerin konut olarak kullanılması, evlerin } \\
\text { korunması ve sürdürülebilirliği açısından olumsuz durum teşkil } \\
\text { etmektedir. }\end{array}$ \\
\hline $\begin{array}{l}\text { Soykan ve Gür } \\
\text { (2015) }\end{array}$ & $\begin{array}{l}\text { Hagios Stephanos Manastırı'nın orijinal dokusunun korunması için } \\
\text { özgün yapılardan farklılık arz eden yapıların kaldırılması } \\
\text { gerekmektedir. }\end{array}$ \\
\hline $\begin{array}{l}\text { Süt ve Kayılı } \\
\text { (2015) }\end{array}$ & $\begin{array}{l}\text { Safranbolu Kürtaliler Konağı iç mekân 1sıl konfor sistemi incelenerek } \\
\text { konağın soğutma yükünden ziyade, yapı malzemelerine bağlı 1sıtma } \\
\text { yüküne sahip olduğu gözlenmiştir. }\end{array}$ \\
\hline $\begin{array}{l}\text { Dönmez, Çabuk, } \\
\text { Öztürk ve Gökyer } \\
\text { (2016) }\end{array}$ & $\begin{array}{l}\text { Safranbolu'nun turistler için bir çekim merkezi olan Çarşı Bölgesi'nde, } \\
\text { otopark alanları yetersiz olup koruma amaçlı imar planında geliştirilen } \\
\text { otopark modeli çözüm sağlamamaktadır. }\end{array}$ \\
\hline $\begin{array}{l}\text { Cengiz, Cengiz ve } \\
\text { Dağlı (2017) }\end{array}$ & $\begin{array}{l}\text { Bartın, Amasra ve Safranbolu kentlerinin özgün peyzaj karakterleri, } \\
\text { turizm potansiyeline olumlu katkı sağlamakta ve bölge ekonomisini } \\
\text { uzun vadede canlandırması açısından önem teşkil etmektedir. }\end{array}$ \\
\hline
\end{tabular}

öncelik sırasında), çevre (somut ve somut olmayan kültürel mirasın sürdürülebilirliği için korunması, turizmi çeşitlendirme fikri, doğal peyzajı bozabilir, kültürel miras değerleri olan 
konakların pansiyon tarzı işletmelere dönüştürülmesi orijinalliği bozmakta, yeni binaların yapılması yerine mevcut yapı stokundan faydalanılması, yabancı turistler, Safranbolu'daki trafik düzenin kötü, eski evlerin çatısındaki güneş enerji panelleri ve uydu alıcılarının görüntü kirliliğini düşünmekte), etik (konaklama işletmelerinin sosyal sorumluluk taşımasının önemi, konaklama işletmeleri engelli bireylere fazla imkânlar sunamamakta), sosyoloji (tarihsel ve doğal yapıyı koruma ve yerel halkın turizmden para kazanma isteği coşku nedenleridir) ve yönetim (konaklama işletmeleri düşük kapasite ile çalışmakta, işgörenler, ücret esnekliği uygulamalarında orta düzeyde katılım göstermekte, destinasyonun sürdürülebilirliği için paydaşlarının fikirleri alınmalı ve birlikte çalışmaları sağlanmalı) olmak üzere dağılım göstermektedir.

Bu bulgular göstermektedir ki Safranbolu turizmine yönelik araştırmalar; eğitim, pazarlama, çevre, etik, yönetim ve sosyoloji boyutlarında destinasyonun geleceğine dair kararların alınmasını öngörmektedir. Bu araştırmaların dikkate alınması Safranbolu turizminin sürdürülebilirliğin sağlanması adına önemli adımlar olacaktır.

Safranbolu mimarisine yönelik tespitler; mimari yapı, mimari yapı özelliği, koruma ve sürdürülebilirlik, iç mekân tasarımı ve mimari görsellik boyutlarında ortaya çımıştır (Tablo 5). Tarihi yapıların konumu ve peyzaj özellikleri, bu yapılarda tarihi dokunun korunması, sürdürülebilirliğinin sağlanması, mimari açıdan önem arz eden yapılarda iç dekorasyonun görsel açıdan özellikleri yapılan çalışmalarda öne çıkarılan temaları oluşturmaktadır.

Coğrafya disiplinine yönelik çalışmalar, Tablo 6'da görüldüğü üzere Safranbolu'nun coğrafi açıdan tarıma elverişli yapısının olduğu, özellikle Safran bitkisinin bölge için tarım açısından önem arz ettiği fakat tarıma gereken değerin verilmediği yönünde yorumlanabilir.

Tablo 6. Safranbolu'ya Yönelik Coğrafya Disiplini Araştırmaları ve Tespitler

\begin{tabular}{|l|l|}
\hline Yazar/Yazarlar & Tespitler \\
\hline $\begin{array}{l}\text { Özdemir } \\
(2001)\end{array}$ & $\begin{array}{l}\text { Safranbolu'ya adını veren Safran bitkisinin ticari değeri dikkate } \\
\text { alındığında yöre halkına önemli gelir sağlamaktadır fakat bitkinin } \\
\text { üretimi azalmış ve sembolik olarak tarımı yapılmaktadır. }\end{array}$ \\
\hline $\begin{array}{l}\text { Özdemir, } \\
\text { Güner ve } \\
\text { Kopar } \\
(2002)\end{array}$ & $\begin{array}{l}\text { Geçici kır yerleşim yerlerinden olan bağ evleri, alaklar ve } \\
\text { sayvanlar özgün kullanımının dışında değerlendirilmektedir. }\end{array}$ \\
\hline $\begin{array}{l}\text { Kiper ve } \\
\text { Arslan } \\
\text { (2007) }\end{array}$ & $\begin{array}{l}\text { Safranbolu'da tarımdan ekonomik yönde bir değer beklenmediği, } \\
\text { üretimde çeşitli kimyasalların kullanılmadığı tespit edilmiştir. Bu } \\
\text { durum ekolojik tarımın tanıtımını ve teşvik edilmesi gerektiğini } \\
\text { ortaya çıkarmıştır. }\end{array}$ \\
\hline $\begin{array}{l}\text { Sarı ve Ören } \\
\text { (2016) }\end{array}$ & $\begin{array}{l}\text { Safranbolu ilçesi briyofit çeşitliliği belirlenerek karayosunlarının } \\
\text { ve ciğerotlarının en zengin familyalar olduğu tespit edilmiştir. }\end{array}$ \\
\hline
\end{tabular}

Tablo 7'de Sosyoloji alanında gerçekleştirilen çalışmalardaki tespitler; üniversitenin kent üzerinde ekonomik ve sosyal açıdan etkili olduğu ve Safranbolu'daki din görevlilerinin yerel toplum ile iletişiminin eğitim durumuna göre farklılık gösterdiği tespit edilmiştir. 
Tablo 7. Safranbolu'ya Yönelik Sosyoloji Disiplini Araştırmaları ve Tespitler

\begin{tabular}{|l|l|}
\hline Yazar/Yazarlar & Tespitler \\
\hline $\begin{array}{l}\text { Sağır ve İnci } \\
(2013)\end{array}$ & $\begin{array}{l}\text { Karabük halkı üniversitenin ekonomik ve sosyal etkilerini } \\
\text { benimsemiş durumdadır. Bunun yanında ekonomik açıdan ev } \\
\text { sahipliği yapan toplumun yetersiz kaldığı söylenebilir. }\end{array}$ \\
\hline $\begin{array}{l}\text { Kaya ve } \\
\text { Küçük } \\
(2015)\end{array}$ & $\begin{array}{l}\text { Safranbolu'da görev yapan din görevlilerinin eğitim durumuna göre } \\
\text { yeterlilikleri değişkenlik göstermektedir. Bu durum yöre halkı ile } \\
\text { olan iletişime de etki etmektedir. }\end{array}$ \\
\hline
\end{tabular}

Safranbolu'ya yönelik Sanat Tarihi alanındaki tespitler ise somut kültürel mirasın yok olmaması ve değerinin anlaşılması yönündedir. Sanat eserlerinin toplumdan ortaya çıkan bir değer olması sebebiyle korunması sürdürülebilirliğinin sağlanması gerektiği Tablo 8'de vurgulanmışır.

Tablo 8. Safranbolu'ya Yönelik Sanat Tarihi Disiplini Araştırmaları

\begin{tabular}{|l|l|}
\hline Yazar/Yazarlar & Tespitler \\
\hline $\begin{array}{l}\text { Özdemir ve } \\
\text { Çelik } \\
(2009)\end{array}$ & $\begin{array}{l}\text { Safranbolu'da yapılan mest üretimi kültürü yok olmadan } \\
\text { belgelenmeli ve orijinal örnekleri müzelerde sergilenmelidir. }\end{array}$ \\
\hline Atmaca & $\begin{array}{l}\text { Safranbolulu Ressam Recai Demirsöz'ün sanatı ve sanat anlayışı } \\
(2015)\end{array}$ \\
\hline
\end{tabular}

\section{TARTIŞMA, SONUÇ VE ÖNERİLER}

Safranbolu ilçesinin mirassal değerleri üzerine farklı disiplinlerde yapılan çalışmaların meta analizi kapsamında irdelendiği bu araştırma ile destinasyonun geleceğine yönelik tavsiye amaçlı katkılar sağlanması amaçlanan bu çalışmada Safranbolu üzerine turizm, mimarlık, coğrafya, sosyoloji ve sanat tarihi olmak üzere beş farklı disiplinde araştırmalar yapıldığı saptanmıştır.

Safranbolu'ya yönelik mimarlık alanında yapılan çalışmalarda miras değeri içeren tarihi binaların özgünlügüunün korunması, restore edilmesi ve yeni imar projeleriyle sürdürülebilirliğin sağlanmasını öne çıkarılmıştır. Coğrafya alanındaki çalışmalarda Safranbolu'nun coğrafi konumu itibariyle önemli bir yerde bulunduğunu, yetiştirilen Safran bitkisinin geçmişten günümüze kalan önemli bir değer olduğu vurgulanmıştır. Sosyoloji disiplininde yapılan çalışmalarda ekonomik, sosyal ve kültürel anlamda yaşanan değişikliklerle destinasyonun şekillenmesi tartışılmıştır. Sanat tarihi çalışmalarında görsel yapıların bölgedeki sanatsal değerlerinin koruma ve kullanma dengesi içerisinde turizm bağlamında kullanılmasının öne çıkartılmıştır. Turizm disiplinindeki çalışmaların ise eğitim, pazarlama, çevre, yönetim, etik ve sosyoloji disiplinleri ile ilişkilendirildiği gözlemlenmiştir. Yerel halkın turizm konusunda bilinçlendirilmesi, destinasyonda satışları artırmak için alternatif ürün ve stratejiler geliştirilmesi, konaklama işletmeleri için yeni yönetim anlayışlarının geliştirilmesi, kültürel mirasa yönelik çevrenin korunması ve destinasyon sürdürülebilirliğine öne çıkartılan araştırma temaları olmuştur.

Bu çalışma, Safranbolu özelinde meta analizi kapsamında yapılmış ilk araştırma niteliği taşımaktadır. Araştırma sonucunda görülmüştür ki Türkiye'de birçok bilimsel araştırma 
yapılmakta ve yeni çıtılar oluşturulmaktadır. Ancak bu araştırmalar, alan yazında yazarlar tarafından çok az olarak bir araya getirilmekte ve analiz bulgularından yararlanılmaktadır. Oysaki Safranbolu özelinde gerçekleştirilen bu çalışmaya benzer nitelikte Türkiye'nin farklı destinasyonları için meta analizi çalışması yapılması ve araştırma çıtılarına bütüncül bakılması, Türkiye turizmin gelişimine oldukça katkı sağlayabilir. Destinasyon gelişiminde rol üstlenebilecek paydaşların farklı işini kolaylaştırabilir.

\section{KAYNAKÇA}

Atmaca, A. E. (2015). Naif Sanat ve Safranbolulu Naif Ressam Recai Demirsöz'ün Sanat Anlayışı. Karabük Üniversitesi Sosyal Bilimler Enstitüsü Dergisi, (Özel Sayı I):36-53.

Ayaz, N. and Demirkol, Ö. (2016). Destination Management in Culture Tourism: The Case of Safranbolu. C. Avcıkurt, M. S. Dinu, N. Hacıoğlu, R. Efe, A. Soykan ve N. Tetik (Editörler). Global Issues and Trends in Tourism.(s. 296-308). Sofia: St. Klıment Ohrıdskı Unıversity Press.

Ayaz, N. ve Yalı, S. (2017). Kültürel Turistlerin Seyahat Tercihleri ve Yiyecek-İçecek Beklentileri: Safranbolu örneği. Türk Turizm Araştırmaları Dergisi, 1(1):43-61.

Ayaz, N., Apak, Ö. C. ve Batı, T. (2016). Yöneticilerin Kültür Turizmi Algısı: Safranbolu Destinasyonu Örneği. Uluslararası Türk Dünyası Turizm Araştırmaları Dergisi, 1(2):84-96.

Ayaz, N., Batı, T. ve Gökmen, F. (2015). Safranbolu'yu Ziyaret Eden Yabanc1 Turistlerin Destinasyon İmajı Algıları. Karabük Üniversitesi Sosyal Bilimler Enstitüsü Dergisi, (Özel Sayı I):54-69.

Bayazıt, N. (2014). Safranbolu Evlerinin Plan Tipolojisi ve Kullanıcı İhtiyaçları Hiyerarşisi. Tasarm+Kuram Dergisi, 10(17):1-15.

Boniface, P. and Fowler, P. J. (1993). Heritage and Tourism in 'The Global Village'. London: Routledge.

Boz, M. ve Uğur, İ. (2015). Tarihi Kentler ve Turizm: Konaklama İşletmeleri Yöneticilerinin Safranbolu'da Turizm Gelişimine İlişkin Algıları. II. International Congress of Tourism \& Management Researches, 01-03 Mayıs, Kuşadası.

Bozkurt, S. G. (2013). 19.yy da Osmanlı Konut Mimarisinde İç Mekan Kurgusunun Safranbolu evleri örneğinde irdelenmesi. Istanbul University Journal of the Faculty of Forestry, 62(2):37-70.

Bozkurt, S. G. ve Altınçekiç, H. (2013). Anadolu'da Geleneksel Konut ve Avluların Özellikleri ile Tarihsel Gelişiminin Safranbolu Evleri Örneğinde İrdelenmesi. Istanbul University Journal of the Faculty of Forestry, 63(1): 69-91.

Cengiz, B., Cengiz, C. ve Dağlı, P. K. (2017). Üniversite Öğrencileri Açısından Kentsel Kültürel Peyzajlarda Karakter Ve Algı Değişimi: Bartın, Amasra, Safranbolu. Kastamonu Üniversitesi Orman Fakültesi Dergisi, 17(1):45-56.

Ceylan, S. ve Somuncu, M. (2016). Kültür Turizmi Alanlarında Turizmin Çeşitlendirilmesine Eleştirel Bir Bakış: Safranbolu UNESCO Dünya Miras Alanı. Uluslararası Türk Dünyası Turizm Araştırmaları Dergisi, 1(1):53-64.

Diker, O. ve Çetinkaya, A. (2016). Erişilebilir Turizm Açısından Safranbolu Turizm Destinasyonunun Uygunluğunun Değerlendirilmesi. Karabük Üniversitesi Sosyal Bilimler Enstitüsü Dergisi, (Özel Sayı II):111-125. 
Doğaner, S. and Dupont, W. (2015). Accelerating Cultural Heritage Tourism in San Antonio: A Community-Based Tourism Development Proposal for The Missions Historic District. International Journal of Sustainable Development and Planning, 10(1):1-19.

Dönmez, Y. Gökyer, E. ve Aşkın, F. K. (2015). Safranbolu Yörük Köyü ve Yakın Çevresinin Ekoturizm Potansiyelinin R'WOT Analizi ile Değerlendirilmesi. Karabük Üniversitesi Sosyal Bilimler Enstitüsü Dergisi, (Özel Sayı I):70-83.

Dönmez, Y., Çabuk, S., Öztürk, M. ve Gökyer, E. (2016). Safranbolu Kentsel Sit Alanında Otopark Sorunu ve Çözüm Alternatifleri. Bartın Orman Fakültesi Dergisi, 18(2):137-145.

Dönmez, Y., Özyavuz, M. ve Gökyer, E. (2015). Safranbolu Kentinin Konut ve Site Alanlarının Yeşil Alan Durumlarının Saptanması. İnönü Üniversitesi Sanat ve Tasarım Dergisi, 5(11):1-12.

Düzgün, E. ve Acar, A. (2016). Safranbolu Turizminin Sürdürülebilir Gelişiminde UNESCO'nun Etkileri. II. Ulusal Sürdürülebilir Turizm Kongresi, 28-30 Nisan, Antalya.

Eker, N., Şengel, Ü. ve Zengin, B. (2015). Safranbolu Turizminin “Doxey Irritation Index" Kapsamında Değerlendirilmesi. I Eurasia International Tourism Congress: Current Issues, Trends, and Indicators, Mayıs, Konya.

Fitri, I., Ahmad, Y. and Ahmad, F. (2015). Conservation of Tangible Cultural Heritage in Indonesia: A Review Current National Criteria for Assessing Heritage Value. Procedia-Social and Behavioral Sciences, (184):71-78.

Gezer, H. (2013). Geleneksel Safranbolu Evlerinin Sürdürülebilirlik Açısından Değerlendirilmesi. İstanbul Ticaret Üniversitesi Fen Bilimleri Dergisi, 12(23):13-31.

Gülcan, B. (2010). Türkiye'de Kültür Turizminin Ürün Yapısı ve Somut Kültür Varlıklarına Dayalı Ürün Farklılaştırma İhtiyacı. İşletme Araştırmaları Dergisi, 2(1):99-120.

Gür, D. ve Soykan, A. N. (2015). Safranbolu, Hagios Stephanos Manastırı (Kilise, Metropolithane, Inas Mektebi, Iskalion Mektebi). Uluslararası Sosyal Araştırmalar Dergisi, 8(36):552-584.

Gürbüz, A. (2002a). Turizmin Sosyal Çevreye Etkisi Üzerine Bir Araştırma. Teknoloji Dergisi, (1-2):49-59.

Gürbüz, A. (2002b). Yerel Kalkınma Stratejisi İçinde Turizm ve Safranbolu. Bilig-Türk Dünyası Sosyal Bilimler Dergisi, 22(Bahar): 29-48.

Gürbüz, A., Cengiz, H. A. and Cengiz, H. (2016). Destination Personality and Attitudes Towards Destination: An Example from Two Similar Tourist Destinations in Turkey. International Journal of Economics, Commerce and Management, 4(5):95-106.

Hacısalihoğlu, İ. Y. (1995). Geleneksel Türk Şehri Safranbolu. Türk Coğrafya Dergisi, (30):409434 .

Harputlugil, G. U. ve Çetintürk, N. (2005). Geleneksel Türk Evi'nde Isıl Konfor Koşullarının Analizi: Safranbolu Hacı Hüseyinler Evi. Gazi Üniversitesi Mühendislik Mimarlık Fakültesi Dergisi, 20(1): 77-84.

Harris, H. (2001). Content Analysis of Secondary Data: A Study of Courage in Managerial Decision Making. Journal of Business Ethics, 34(3):191-208.

İnci, Ü. H. ve Sağır, A. (2013). Karabük'te Üniversite Algısı: Karabük Üniversitesi Örneği. İnsan ve Toplum Bilimleri Araştırmaları Dergisi, 2(2): 49-81. 
İşler, E. ve Aras, R. (2013). Kastamonu Merkez, Daday ve Safranbolu Geleneksel Türk Evi Tavanları. Akdeniz Sanat Dergisi, 6(11):166-180.

İsmail, N., Masron, T. and Ahmad, A. (2014). Cultural Heritage Tourism in Malaysia: Issues and challenges. SHS Web of Conferences, 1-8.

Kalamarova, M., Loucanova, E., Parobek, J. and Supin, M. (2015). The Support of the Cultural Heritage Utilization in Historical Town. Procedia Economics and Finance, (26):914-919.

Karakaya, A. ve Uçar, M. (2015). İş Esnekliğinin İşgören Motivasyonuna Etkisi. Karabük Üniversitesi Sosyal Bilimler Enstitüsü Dergisi, (Özel Sayı I):19-35.

Karakuş, U., Çepni, O. ve Kılcan, B. (2011). İlköğretim İkinci Kademe Öğrencilerinin Turizme Yönelik Görüşlerinin Çeşitli Değisskenler Açısından İncelenmesi (Safranbolu'da Nicel Bir Çalışma). Pegem Eğitim ve Öğretim Dergisi, 1(4):85-95.

Kaya, H. and Kurt H. (2011). Contribution of Concrete Cultural Constituents to The Tourism Potential of Safranbolu. Procedia Social and Behavioral Sciences, (19):225-230.

Kaya, M. ve Küçük, N. (2015). Din Görevlilerinin Mesleki Yeterlilikleri: Safranbolu'da Görev Yapan Din Görevlileri Üzerine Bir Araştırma. Karabük Üniversitesi Sosyal Bilimler Enstitüsü Dergisi, (Özel Sayı I): 1-18.

Kılıç, S. E. ve Türkoğlu, G. (2015). Conservation Problems of Traditional Housing with Continued Original Function and Recommended Solutions: Safranbolu "Eski Çarşı District". Megaron, 10(2):260-270.

Kılıç, S. E. ve Türkoğlu, G. (2015). Geleneksel Yapılarda Konaklama Amaçlı Fonksiyon Değişiklikleri: Safranbolu Eski Çarşı Örneği. Ege Coğrafya Dergisi, 24(1):39-56.

Kiper, T. ve Arslan, M. (2007). Safranbolu-Yörükköyü Tarımsal Turizm Potansiyelinin Kırsal Kalkınma Açısından Değerlendirilmesi. Süleyman Demirel Üniversitesi Orman Fakültesi Dergisi, (2):145-158.

Koçan, N. ve Çorbacı, Ö. L. (2012). Tarihi Çevreleri Koruma Sürecinde Yeni Yaklaşımlar: Kongre Turizmi, Safranbolu Çarşı Örneğinde Bir Araştırma. Mehmet Akif Ersoy Üniversitesi Fen Bilimleri Enstitüsü Dergisi, 3(2):31-36.

Külcü, Ö. T. (2015). Kültürel Miras Kavramının Eğitim Açısından Önemi. Akademia Disiplinlerarası Bilimsel Araştırmalar Dergisi, 1(1):27-32.

Lenzerini, F. (2011). Intangible Cultural Heritage: The Living Culture of Peoples. The European Journal of International Law, 22(1):111-112.

Lynch, M., Duinker, P. N., Sheehan, L. R. and Chute, J. E. (2011). The Demand for Mi'kmaw Cultural Tourism: Tourist Perspectives. Tourism Management, 32(5):977-986.

Özdemir, M. ve Çelik, D. (2009). Safranbolu İlçesinde Mest Yapımı. Karadeniz, 5(17):133-147.

Özdemir, Ü. (2001). Safranbolu ve Safran Tarımı. Doğu Coğrafya Dergisi, 7(5):295-308.

Özdemir, Ü. (2011). Safranbolu'nun Kültürel Miras Kaynakları ve Korunması. Doğu Coğrafya Dergisi, 16(26):129-142.

Özdemir, Ü., Güner, İ. ve Kopar, İ. (2002). Safranbolu Platosunda Geçici Kır Yerleşmeleri. Doğu Coğrafya Dergisi, 7(7):133-152.

Sarı, B. ve Ören, M. (2016). Safranbolu İlçesi (Karabük) Briyofit Florası. Kastamonu Üniversitesi Orman Fakültesi Dergisi, 16(1):157-168. 
Seker, D. Z., Alkan, M., Kutoglu, H., Akcın, H. ve Kahya, Y. (2010). Development of A Gis Based Information and Management System for Cultural Heritage Site; Case Study of Safranbolu. FIG Congress Facing the Challenges-Building the Capacity, 11-16 April, Sydney.

Soykan, A. N. ve Gür, D. (2015). Safranbolu, Yazıköy Kilise (Mimari, Süsleme, Liturjik Elemanlar). Karabük Üniversitesi Sosyal Bilimler Enstitüsü Dergisi, (Özel Sayı I):103-129.

Süt, G. ve Kayılı, M. T. (2015). Özgün ve Özgün Olmayan Yapı Bileşenlerine Göre Geleneksel Yapıların Enerji Performansının Karşılaştııılması. 12. Ulusal Tesisat Mühendisliği Kongresi, 8-11 Nisan, İzmir.

Türker, A. ve Çelik, İ. (2012). Somut Olmayan Kültürel Miras Unsurlarının Turistik Ürün Olarak Geliştirilmesine Yönelik Alternatif Öneriler. Yenifikir Dergisi, (9):86-98.

Türker, N. (2013). Host Community Perceptions of Tourism Impacts: A Case Study on The World Heritage City of Safranbolu Turkey. Revista de Cercetareşi Interventie Socialâ, (43):115141.

Uslu, A. ve Kiper, T. (2006). Turizmin Kültürel Miras Üzerine Etkileri: Beypazarı/Ankara Örneğinde Yerel Halkın Farkındalığı. Tekirdağ Ziraat Fakültesi Dergisi, 3(3):305-314.

Uygur, S. M. ve Baykan, E. (2007). Kültür Turizmi ve Turizmin Kültürel Varlıklar Üzerindeki Etkileri. Ticaret ve Turizm Ĕ̆itim Fakültesi Dergisi, (2):30-49.

Yaman, K. (2015). Yabancı Turistlerin Safranbolu'daki Çevre Kirliliği Algısı. Karabük Üniversitesi Sosyal Bilimler Enstitüsü Dergisi, (Özel Sayı I):84-102.

Yılmaz, K.G., Karaman, E. ve Karaman, G. (2013). Marka Şehir Olabilmenin Yeni Boyutu: Kullanılabilirlik. Journal of Tourism and Gastronomy Studies, 1(4):69-76.

Yüksel, İ. (2013). Turizmde Mekansal Altyapının Karşılanmasında Yerel Fırsatların Değerlendirilmesi. Sosyal ve Beşeri Bilimler Dergisi, 5(2):179-191. 